\title{
Pendidikan Berbasis Kesetaraan Gender Di Provinsi Jawa Tengah
}

\section{Education Based on Gender Equality in Central Java Province}

\author{
Ali Roziqin $^{\text {a, }}{ }^{*}$, Sri Suwitri ${ }^{\text {b, Ach. Ahmad Apryanto }}$. Iradhad Taqwa Sihidi ${ }^{a}$ \\ ${ }^{a}$ Ilmu Pemerintahan, Fakultas Ilmu Sosial dan Ilmu Politik, Universitas Muhammadiyah Malang, Indonesia \\ b Ilmu Administrasi Publik, Fakultas Ilmu Sosial dan Ilmu Politik, Universitas Diponegoro, Indonesia \\ ${ }^{1}$ aliroziqin@umm.ac.id* \\ *korespondensi penulis
}

\begin{tabular}{l}
\hline Informasi artikel \\
\hline Kata kunci: \\
Pendidikan Perempuan, \\
Kebijakan Publik, Kesetaraan \\
Gender
\end{tabular}

\begin{abstract}
ABSTRAK
Pada tahun 2030 Indonesia diprediksi akan memperoleh bonus demografi. Disisi lain diskriminasi dan keadilan belum terselesaikan di Negara ini, terutama pendidikan perempuan. Pendidikan merupakan media yang sangat ampuh untuk memperjuangkan hak-hak perempuan yang selama ini masih termarginalisasi. Usaha untuk meningkatkan pendidikan perempuan selama ini masih terbentur oleh beberapa hal seperti kebijakan publik yang belum pro terhadap kesetaraan dan keadilan gender. Terbatasnya akses pendidikan menyebabkan perempuan terperangkap pada keterbelakangan. Selain itu juga persepsi masyarakat dan tingginya budaya patriarki yang masih memandang sebelah mata terhadap perempuan. Meningkatnya akses pendidikan terhadap perempuan akan memberikan konstribusi positif dalam kesetaraan gender guna mempersiapkan generasi mendatang yang unggul khususnya di Provinsi Jawa Tengah.
\end{abstract}

\section{Keywords: \\ Women Education, Public Policy, Gender Equality}

\section{ABSTRACT}

Education Based on Gender Equality in Central Java Province. In 2030,

Indonesia is predicted will receive a demographic dividend. On the other side, discrimination and equality have unresolved in this country, especially is female education. Education is powerful media to fight on the right of females who are still marginalized. Efforts to improve women's education so far have been hampered by several things such as public policies that have not been pro to equality and produce gender. Limited access to education leaves women trapped in underdevelopment. In addition, the community also values a patriarchal culture that still underestimates women. Increased access to education for women will make a positive contribution to gender equality in order to prepare future generations who excel specifically in Central Java Province.

\begin{abstract}
Pendahuluan
Hakikatnya seorang manusia dilahirkan mempunyai kesempatan yang sama dalam memperoleh akses-akses kehidupan. Termasuk dalam hal pendidikan. UNESCO sebagai organisasi dunia yang mewenangi masalah pendidikan menjelaskan pendidikan terdiri dari empat pilar utama. Pertama adalah berorientasi pada how to know (pengetahuan/kognitif), How to do (keterampilan/psikomotorik), how to be (sikap/afeksi) dan how to live together (Mustaqim, 2014). Lelaki dan perempuan dibanyak tempat dipisahkan secara tegas melalui pengakuan dan pengingkaran sosial, ekonomi, politik. Pemisah ini telah mengakibatkan "ketimpangan gender" yang secara otomatis
\end{abstract}

menimbulkan bias gender di masyarakat. Ketimpangan yang terjadi tidak hanya bersifat kultural akan tetapi juga struktural. Hal semacam inilah yang kemudian mendorong beberapa studi tentang kesetaraan gender.

Perempuan yang sekarang ini jumlahnya lebih besar dibanding laki-laki belum banyak mengisi dan menempati structural organisasi publik. Mereka belum banyak ikut andil di dalam menentukan keputusan-keputusan dan kebijakan penting. Dikotomi laki-laki dan perempuan juga tercermin dalam segregasi pekerjaan antara perempuan dan laki-laki. Pembedaan laki-laki dan perempuan ini disebabkan oleh faktor social dan budaya (Susilastuti, 1997). Kedudukan perempuan dan laki-laki di masyarakat masih 
didominasi oleh laki-laki. Hal ini tentu bertentangan dengan hakikat manusia yang dilahirkan sama dan mempunyai kesempatan yang sama, tidak ada diskriminasi dan pengkhususan tertentu. Salah satu hal penyebab ketimpangan tersebut adalah karena kurangnya akses pendidikan.

Di Provinsi Jawa Tengah angka pernikahan dini masih sangat tinggi. Para gadis muda terpaksa harus nikah dini karena tidak ada hal lain yang bisa mereka lakukan kecuali menjadi Ibu rumah tangga. Ada sekitar 11 persen perempuan usia 20-24 tahun sudah menikah atau hidup bersama sebelum berusia 18 tahun pada tahun 2015 (Unicef \& Bappenas, 2015). Kondisi ini biasanya terjadi di kalangan anak perempuan dari rumah tangga miskin. Nilai gender patriarki yang diajarkan secara terus menerus, berdampak pada realitas objektivitas yang semakin kuat. Sehingga nilai-nilai ini dianggap sebagai kebenaran ideologis yang bersifat mutlak dan mempunyai daya paksa.

Perbedaan gender yang terkadung didalamnya sebenarnya tidak menjadi masalah asalkan tidak menimbulkan ketidakadilan gender. Kesenjangan gender atau bias gender itu muncul ketika perbedaan gender membawa ketidakadilan dalam berbagai bentuk, terutama bagi perempuan. Untuk memahami bagaimana ketidakadilan gender, perlu manifestasi dalam berbagai bentuk seperti marginalisasi atau proses pemiskinan ekonomi, subordinasi atau anggapan tidak penting dalam keputusan politik, pembentukan stereotype atau label negatif, kekerasan (violence), beban kerja lebih lama, serta sosialisasi ideology nilai peran gender (Marzuki, 2008); (Fakih, 1997).

Masalah gender merupakan salah satu masalah sosial yang bisa menghambat perkembangan masyarakat. Oleh karena itu perlu diusahakan langkah terus menerus dan antisipatif. Secara organisasi internasional, konferensi perempuan sedunia di Beijing tahun 1995 sepakat berkomitmen untuk memperjuangkan dan menghapuskan ketidakadilan gender ini. Dalam konferensi tersebut menjelaskan beberapa ketidakadilan gender dalam pendidikan sehingga berdampak pada kondisi, status, dan posisi perempuan yang lemah dalam keluarga, sosial masyarakat dan kehidupan berbangsa.

Berbicara tentang ketimpangan gender dalam pendidikan, lebih banyak disebabkan oleh faktor sosial budaya yang hidup di dalam masyarakat. Faktor sosial budaya menganggap bahwa anak perempuan tidak perlu sekolah tinggi karena berakhir ke dapur juga. Anggapan ini masih sangat kuat dalam kultur jawa. Bagi anak laki-laki, secara sosial budaya dikonstruksikan sebagai penyangga ekonomi keluarga sehingga mereka harus bertanggung jawab untuk ikut membantu meringankan beban ekonomi keluarga sehingga merekalah yang lebih diutamakan untuk sekolah. Tercatat pada tahun 2017 ada kurang lebih 12,23\% atau 4,2 juta pupulasi dibawah garis kemiskinan nasional. Oleh karena itu artikel ini bertujuan untuk menganalisis bagaimana pendidikan perempuan yang ada di Provinsi Jawa Tengah. Kemudian bagaimana kebijakan publik khususnya kebijakan dalam bidang pendidikan untuk mewujudkan kesetaraan gender.

Dalam artikel ini penulis menggunakan tinjauan pustaka dan penelitian terdahulu yang membahas tentang bagaimana pendidikan kesetaraan gender. Lebih khusus lagi pendidikan untuk perempuan yang ada di Provinisi Jawa Tengah.

\section{Metode}

Pendidikan berbasis kesetaraan gender di Jawa tengah mempunyai urgensitas sebagai isu terkini. Hal itu dikarenakan kultur dan realita sosial yang patriarki. Artikel ini menggunakan metode kualitatif deskriptif yang bersifat studi literatur. Menurut (Creswell \& Clark, 2010) penelitian kualitatif adalah metode untuk mengeksplorasi dan memahami makna yang berasal dari masalah sosial atau kemanusiaan. Penulis mengumpulkan data-data sekunder dan dianalisa dengan teori yang ada. Data sekunder bisa berupa angka dan narasi seperti penelitian terdahulu yang terkait dengan pendidikan perempuan, ketimpangan gender serta laporan dari organisasi publik (pemerintah)

\section{Hasil dan pembahasan \\ 1) Pendidikan dan Gender}

Menurut Undang-Undang No 20 tahun 2003 tentang Sistem Pendidikan Nasional, pendidikan merupakan usaha secara sadar dan terencana untuk mewujudkan suasana belajar dan proses pembelajaran agar peserta didik secara aktif mengembangkan potensi dirinya untuk memiliki kekuatan spiritual keagamaan, pengendalian diri, kepribadian, kecerdasan, akhlak muliah serta keterampilan yang diperlukan dirinya, masyarakat bangsa dan Negara. Melalui pendidikan diharapkan dapat tercipta manusia berkualitas yang mampu membangun dan 
meningkatkan kesejahteraan masyarakat pada umumnya.

Sedangkan berbicara tentang gender, berbeda dengan seks atau jenis kelamin. Seks merupakan perbedaan antara laki-laki dan perempuan didasarkan pada bentuk biologis, maka gender adalah perbedaan laki-laki dan perempuan berdasarkan konstruk sosial yang budaya yang tercipta (Wahid, 2003). Gender bukan merupakan property individual namun merupakan interaksi yang sedang berlangsung antar aktor dan struktur dengan variasi yang sangat besar antara kehidupan laki" dan perempuan secara individual sepanjang siklus hidupnya secara structural dalam sejarah ras dan kelas (Feree, 1990,) (Llyod et al, 2009) dalam (Puspitawati, 2013). Gender merupakan konstruksi sosial yang terbangun atas peranperan yang menjadi hak dan kewajiban antara laki-laki dan perempuan secara proporsional. Konstruksi sosial akibat misunderstanding menyebabkan masalah-masalah unequal dan unbalance opportunity (Susanti, 2015).

Kesenjangan gender dalam pendidikan adalah perempuan lebih dibatasi untuk memperoleh akses pendidikan. Semakin tinggi jenjang pendidikan, semakin lebar kesenjanganya antara laki-laki dan perempuan. Kesenjangan ini berdampak pada perbedaan rata-rata penghasilan laki-laki dan perempuan (Fakih, 2005). Menurut Mursidah, kesenjangan gender bidang pendidikan dapat dilihat dari segi buku pelajaran seperti, bahasa dan sastra, IPS, Pendidikan Kewarganegaraan, Pendidikan Jasmani, Kesenian dan lain sebagainya. Mata pelajaran tersebut banyak membahas tentang kedudukan perempuan dalam masyarakat cenderung masih menganut nilai-nilai yang diskriminatif dan bias gender. Kurikulum dan materi pelajaran yang belum mengacu kepada prinsip-prinsip kesetaraan gender dan keadilan gender akan menyebabkan perempuan tidak mempunyai mentalitas sebagai warga negara yang produktif.

Provinsi Jawa Tengah termasuk provinsi dengan jumlah penduduk muda yang signifikan. Pada tahun 2017 jumlah penduduk Provinsi Jawa Tengah adalah 34.257.865 jiwa yang terdiri dari 16.988.093 jiwa penduduk adalah laki-laki dan 17.269.772 jiwa penduduk adalah perempuan. Dari jumlah tersebut setidaknya jumlah usia produktif penduduk perempuan adalah 18.010.612. Sedangkan untuk angka partisipasi pendidiakn pada jenjang pendidikan SMP dan
SMA di jawa tengah angkanya tidak terlalu bagus. Seperti bisa dilihat dibawah ini:

Tabel 1.1 Angka Partisipasi Pendidikan di Provinsi Jawa Tengah

\begin{tabular}{l|l|l|l} 
No & $\begin{array}{l}\text { Jenjang } \\
\text { Pendidikan }\end{array}$ & APM & APK \\
\hline 1 & SD/MI & 97,13 & 108,44 \\
\hline 2 & SMP/MTs & 79,13 & 91,09 \\
\hline 3 & SMA/SMK & 59,20 & 84,39
\end{tabular}

Sumber: Provinsi Jawa Tengang Dalam Angka 2018

Selama ini kebijakan pendidikan lebih banyak dikontrol oleh laki-laki karena mereka lebih mempunyai posisi strategis dalam pengelolaan pendidikan, terutama dalam jabatan struktural, mulai dari tingkat pusat hingga daerah. Fakta-fakta semacam inilah yang menyebabkan terjadinya bias gender dalam bidang pendidikan. Menurut Susanti factor penyebab bias gender dapat dikategorikan menjadi tiga aspek yaitu partisipasi, akses dan kontrol. Meskipun ketiga aspek itu tidak bisa menjelaskan bias gender secara empiris dalam bidang pendidikan.

Upaya untuk meminimalisasi ketimpangan gender adalah meningkatkan pengetahuan masyarakat tentang gender. Salah satunya adalah pengembangan kurikulum. Hal ini seperti yang disampaikan dalam penelitian Mustqim. Menurut Undang-Undang No.20 tahun 2003, dijelaskan bahwa kurikulum merupakan seperangkat rencana dan pengaturan mengenai tujuan, isi dan bahan pelajaran serta tatacara yang digunakan sebagai pedoman penyelenggaraan kegiatan belajar mengajar untuk mencapai tujuan pendidikan tertentu. kurikulum kesetaraan gender (IKKG) dengan nilai-nilai integritas pada kurikulum.

Dalam proses pengembangan kurikulum yang berbasis gender, ada beberapa pamangku kepentingan yang dijelaskan oleh David G. Amstrong yaitu: Curriculum specialist (spesialis kurikulum, ahli kurikulum); Teacher/instructors (guru/instruktur); Learners (peserta didik); Principals/corporate unit supervisors (kepala sekolah/unit pengawas sekolah); Central office administrators/corporeate administrators (administrator kantor pusat/administrator perusahaan; Special experts (ahli special); Lay public representatives (perwakilan masyarakat umum). Apa yang dimaksud dengan pengembangan kurikulum adalah proses perencanaan dan penyusunan kurikulum oleh pengembang kurikulum (curriculum developer) 
dan kegiatan yang dilakukan agar kurikulum yang dihasilkan dapat menjadi bahan ajar dan acuan yang digunakan untuk mencapai tujuan pendidikan nasional. Selanjutnya, materi dalam kurikulum harus diorganisasikan dengan baik agarsasaran (goals) dan tujuan (objectives) yang telah ditetapkan.

Saat ini mayoritas institusi pendidikan di Jawa Tengah menggunakan kurikulum 13. Menurut Mulyasa (2006) K13 adalah kurikulum operasional yang disusun dan dilaksanakan oleh satuan pendidikan dengan tujuan meningkatkan mutu pendidikan, meningkatkan kepedulian warga sekolah terhadap pengembangan kurikulum, meningkatkan kompetisi yang sehat antar satuan pendidikan. Melalui keleluasaan ini diharapkan satuan pendidikan memberikan atensi lebih terhadap isu gender dalam dunia pendidikan.

Setelah kurikulum, langkah yang bisa dilakukan oleh provinsi jawa tengah adalah melakukan pembinaan kepada seluruh unsur pendidikan mengenai proses pembelajaran yang sensitif gender. Keterlibatan seluruh stakeholders sangat dibutuhkan bagi terwujudnya kehidupan yang lebih egaliter. Kesetaraan gender dalam proses pembelajaran memerlukan keterlibatan pemerintah sebagai pengambil kebijakan di bidang pendidikan, sekolah secara kelembagaan dan terutama tutor/pengajar. Dalam hal ini diperlukan standardisasi buku ajar yang salah satu kriterianya adalah berwawasan gender. Selain itu, guru akan menjadi agen perubahan yang sangat menentukan bagi terciptanya kesetaraan gender dalam pendidikan melalui proses pembelajaran yang peka gender.

Dalam wacana feminisme, kesetaraan merupakan yang sangat prinsipil. Bagaimana permasalahan ketimpangan gender bisa diatasi? Yaitu melalui pendidikan. Langkah konkrit yang bisa dilakukan oleh pemangku kepentingan tingkat provinsi jawa tengah adalah:

1. Membuka kesempatan pendidikan yang lebih merata pada semua jurusan, jenis, dan tingkat pendidikan tanpa adanya diskriminasi dan mewujudkan kesetaraan gender.

2. Meminimalisasi kesetaraan gender di semua level pendidikan.

3. Memberikan peluang dan kesempatan yang besar kepada perempuan untuk berpartisipasi secara optimal pada semua unit dan dalam seluruh tahapan proses kebijakan pendidikan.
Sementara yang disebutkan dalam penelitian Sofyan, pada sekolah menengah kejuruan (SMK) yang dulunya disebut SMEA dan STM. SMK selalu identik dengan laki-laki sedangkan pada Sekolah Menengah Ekonomi dan Akuntansi (SMEA) banyak ditemukan para siswa didominasi oleh kaum perempuan. Hal ini beralasan karena sekolah kejuruan ini membidangi ilmu kesekretariatan yang pada umumnya profesi tersebut secara empirik cenderung melekat pada jiwa perempuan. Sebaliknya jika kita meninjau ke Sekolah Menengah Teknik lebih banyak didominasi oleh siswa laki-laki dengan pertimbangan ilmu-ilmu teknik seperti permesinan, elektronika, serta bangunan dan ilmu-ilmu teknik yang lain identik dengan pekerjaan yang harus dikuasai oleh kaum laki-laki (Sofyan, 2012). Stereotif ini juga terjadi dalam dunia seni (pendidikan) yang berpengaruh terhadap sistem minat kesenian di masyarakat.

Dalam mewujudkan kesetaraan gender dalam bidang pendidikan selain dalam bentuk kurikulum dan unsur tenaga pendidik juga dapat disebarkan pada berbagai mata pelajaran dalam mendukung pengembangan. Adapun langkahlangkah menurut Mursidah (2013) adalah sebagai berikut:

1. Merumuskan visi, misi tujuan sekolah dan pengembangan diri yang berbasis kesetaraan gender.

2. Mengkaji standar kompetensi dan kompetensi dasar kesetaraan gender yang diintegrasikan dengan kesetaraan gender.

3. Mengintegrasikan nilai-nilai tersebut ke dalam indikator dan atau kegiatan pembelajaran pada silabus dan rencana pembelajaran.

Selama ini pendidikan gender di Jawa Tengah bisa kita temui di beberapa mata pelajaran seperti IPS, bahasa Indonesia, PPKN, Pendidikan jasmani dan olahraga dan lain sebagainya. Beberapa mata pelajaran ini baik di semua jenjang ditujukan bagi pembinaan generasi penerus terutama pada usia dini agar memahami potensi dan peran dirinya dalam berbagai tata kehidupannya. Menghayati keharusan dan pentingnya bermasyarakat dengan penuh rasa kebersamaan dan kekeluargaan serta mahir berperan di lingkungannya sebagai insan sosial dan warga negara yang baik. Dengan pemahaman tersebut ketimpangan gender yang selama ini telah terbentuk di masyarakat akan sedikit demi sedikit berkurang. 
Menurut Susanti, (2015) bahan ajar atau materi ajar yang diberikan di institusi pendidikan mempunyai peran besar dalam memberikan pemahaman terhadap fenomena "gender" kepada siswa. Bahan ajar yang berwawasan gender adalah: bahan ajar yang sensitif terhadap isu gender yaitu mengajarkan, memperlakukan, menggambarkan keadilan dan kesetaraan antara perempuan dan laki-laki di dalam memperoleh akses, partisipasi, kontrol dan manfaat dalam berbagai segi kehidupan serta penguasan terhadap sumber-sumber teknologi dan informasi; menggambarkan potret perempuan dan laki-laki yang dinamis dalam setting

Dengan memahami literatur dan bahan bacaan yang peka terhadap kesetaraan gender. Diharapkan peserta didik akan lebih mampu memahami, mensosialisasikan, dan berperan secara multidisiplin terhadap permasalahan gender. Hal ini sebagai lamgkah preventif sejak dini yang bisa diintegrasikan dalam proses dan tahap pembelajaran. Pembelajaran ini dilaksanakan oleh guru kepada anak-anak dan berlangsung sepanjang waktu. Harapan guru siswa perlu ditekankan untuk aktif di dalam kelas dan aktif untuk bertanya sehingga ada interaksi antara guru dengan siswa yang menunjukkan kegiatan pembelajaran dapat berjalan. Melalui proses belajar mengajar, dan sistem pendidikan yang sensitif gender secara menyeluruh kesetaraan gender bisa diwujudkan.

\section{Kebijakan Pendidikan Perempuan}

Dalam konstruksi barat, ada beberapa masalah yang terkait dengan gender yaitu gender differention, gender equality dan gender oppression. Hal yang sama juga terjadi di tingkat lokal, Banyak sekali permasalahan yang belum terselesaikan hari ini. Salah satunya adalah tentang kesetaraan gender. Dalam Women's Studies Encyclopedia gender didefinisikan sebagai konsep kultural yang membuat pembedaan dalam hal peran. Perilaku, mentalitas dan karakteristik emosinoal antara laki-laki dan perempuan yang berkembangan dalam masyarakat. Pembedaan ini disadari atau tidak telah melahirkan bagi kaum perempuan. Salah satunya adalah terkait degan akses pendidikan.

Kebijakan publik merupakan sebuah cara yang bisa dilakukan pemerintah dalam bentuk program untuk mencapai sasaran dan tujuan (Suwitri, 2008). Dalam memperjuangkan kesetaraan gender Indonesia telah melaksanakan berbagai kebijakan dari konvensi PBB melalui
Undang-Undang RI Nomor 7 Tahun 1994 tentang Pengesahan Konvensi Mengenai Penghapusan Segala Bentuk Diskriminasi Terhadap Wanita (Convention on the Elimination of All Formers of Discrimination Against Women); Undang-Undang Republik Indonesia No. 34 tahun 199 tentang Hak Asasi Manusia berhak untuk memperoleh pendidikan sesuai dengan persyaratan yang telah ditentukan. Dalam undang-undang tersebut terdapat Pasal 60 ayat (1) menyatakan setiap anak berhak untuk memperoleh pendidikan dan pengajaran dalam rangka pengembangan pribadinya sesuai dengan aksesoris personal yang melekat (Warni, 2015).

Kondisi pendidikan di Jawa Tengah kondisinya memang tidak terlalu bagus dimana presentase menamatkan pada satu jenjang pendidikan tidak terlalu tinggi. Seperti yang dijelaskan tabel dibawah ini:

Tabel 1.2 Keadaan Pendidikan di Jawa Tengah

(Presentase Penduduk Umur 10 Tahun ke Atas Menurut Pendidikan Tertinggi yang Ditamatkan)

\begin{tabular}{|c|c|c|c|c|}
\hline \multirow[t]{2}{*}{ No } & \multirow{2}{*}{$\begin{array}{l}\text { Jenjang } \\
\text { Pendidikan }\end{array}$} & \multicolumn{3}{|c|}{ Tahun } \\
\hline & & 2015 & 2016 & 2017 \\
\hline 1 & $\begin{array}{l}\text { Diploma/Univer } \\
\text { sitas }\end{array}$ & $\begin{array}{l}5.37 \\
\%\end{array}$ & $5.50 \%$ & $5.44 \%$ \\
\hline 2 & SMA/MA & $\begin{array}{l}16.40 \\
\%\end{array}$ & $\begin{array}{l}18.34 \\
\%\end{array}$ & $\begin{array}{l}18.12 \\
\%\end{array}$ \\
\hline 3 & SMP/MTs & $\begin{array}{l}19.80 \\
\%\end{array}$ & $1.20 \%$ & $\begin{array}{l}21.37 \\
\%\end{array}$ \\
\hline 4 & SD/MI & $\begin{array}{l}32.31 \\
\%\end{array}$ & $\begin{array}{l}37.32 \\
\%\end{array}$ & $\begin{array}{l}30.84 \\
\%\end{array}$ \\
\hline 5 & $\begin{array}{l}\text { Tidak/belum } \\
\text { tamat SD }\end{array}$ & $\begin{array}{l}19.54 \\
\%\end{array}$ & $\begin{array}{l}19.91 \\
\%\end{array}$ & $\begin{array}{l}18.96 \\
\%\end{array}$ \\
\hline 6 & $\begin{array}{l}\text { Tidak/Belum } \\
\text { sekolah }\end{array}$ & $6.58 \%$ & $3.73 \%$ & $5.27 \%$ \\
\hline
\end{tabular}

Sumber: Statistik Kesejahteraan Rakyat Prov. Jawa Tengah, 2017

Pendidikan perempuan yang tidak memadai di Jawa tengah banyak disebabkan oleh faktor ekonomi seperti kemiskinan. Dimana data tahun 2015 menyebutkan ada sekitar 1.5 juta anak yang hidup dibawah garis kemiskinan. Faktor ekonomi keluarga adalah faktor terbesar, dimana pendapatan keluarga yang terbatas berdampak pada pilihan sulit untuk menentukan siapa yang harus tetap bersekolah. Biasanya dalam pengambilan keputusan tersebut anak laki-laki lah yang akan mendapat prioritas. Faktor ekonomi seringkali juga menjadi penyebab orang 
tua tidak mau menyekolahkan anaknya jika tempat sekolah yang dituju berada jauh di luar desa dan harus menggunakan transportasi. Hal ini tentu sangat memberantakan bagi keluarga ekonomi lemah untuk menambah biaya pendidikan terkhusus biaya transportasi pendidikan. Faktor lainya yaitu faktor budaya yang menghambat perempuan. Seperti misalnya menyekolahkan anak laki-laki jauh lebih menguntungkan daripada perempuan. Kemeredekaan perempuan dan kreativitasnya seringkali dibatasi sehingga tidak dapat mengembangkan nilai-nilai kemanusiaanya (Freire, 1999).

Isu gender lainnya dalam dunia pendidikan adalah persoalan bias gender dalam berbagai mata pelajaran, mulai dari tingkat taman kanak-kanak, SD, SMP, SMA, Sekolah Kejuruan, dan Keaksaraan Fungsional. Beberapa mata pelajaran seperti Matematika, IPS, IPA, Kesehatan dan Jasmani, PKn, Bahasa Indonesia sering ditemui adanya bias gender. Bahkan dapat dilihat dari porsi pengarangnya ternyata lebih banyak pengarang laki-laki dibandingkan dengan pengarang perempuan. Namun, pengarang perempuan pun belum menjamin bahwa buku yang dikarangnya mempunyai perspektif gender. Desakan untuk mengubah kurikulum dan bahan ajar agar lebih peka gender dinilai sangat mahal dan memerlukan waktu lama. Oleh karena itu, perlu dilakukan berbagai upaya terobosan untuk mengurangi bias gender di institusi pendidikan, baik itu secara formal ataupun non formal.

$$
\text { Permasalahan gender harus }
$$

disosialisakan kepada setiap individu baik lakilaki atau pun perempuan. Sosialisasi itu berupa bagaimana perempuan harus diberikan hak untuk mengenyam dunia pendidikan sama dengan lakilaki. Melalui sosialisasi inilah diharapkan dampak negatif dari bias gender bisa diminimalisir. Hal itu dilakukan secara menyeluruh mulai dari tingkat pendidikan yang paling rendah hingga tinggi. Pendidikan bagi perempuan akan mempunyai signifikansi untuk memperbaiki kesenjangan gender. Misalnya, dengan kualifikasi pendidikan seorang perempuan akan lebih mempunyai kesempatan memperoleh akses-akses kerja secara luas. Di samping itu dengan pekerjaan yang dia miliki, seorang perempuan bisa lebih berdikari dan tidak tergantung kepada seorang laki-laki (suami-istri). Sehingga diskriminasi, marginalisasi, dan kekerasan perempuan sebagai akibat dari bias gender tidak terjadi.
Menurut penelitian Mursidah partisipasi perempuan yang rendah pada jenjang pendidikan khususnya pendidikan tinggi seperti SMA/SMK, dan Perguruan Tinggi, setidaknya 3 alasan yang dapat dijelaskan:

1. Tidak tersedianya sarana dan prasarana sekolah untuk jenjang pendidikan SMA/Sederajat dan keatas di daerah sekitar tempat tinggal. Sehingga hal ini menjadi pertimbangan dan keberatan bagi orang tua untuk menyekolahkan anaknya.

2. Tingginya biaya pendidikan. Untuk provinsi Jawa tengah, pada jenjang pendidikan SMA/SMK para siswa mulai diberlakukan biaya SPP. Kondisi ini tentu akan sangat memberatkan bagi keluarga yang tidak mampu

3. Masih adanya norma di masyarakat yang merugikan perempuan misalnya pandangan yang menytakan bahwa perempuan lebih diperlukan untuk membantu orang tua dan menyelesaikan pekerjaan sehari-hari di rumah. Sedangkan laki-laki memiliki tanggung jawab yang lebih besar.

Akibat dari rendahnya pendidikan bagi perempuan, ketidakadilan dan ketimpangan gender masih sering terjadi dalam berbagai bentuk (Efaningrum, 2008):

1) Marginalisasi terhadap Perempuan Marginalisasi berarti menempatkan atau mengeser perempuan kepinggiran. Perempuan dicitrakan lemah, kurang atau tidak rasional, kurang atau tidak berani sehingga tidak pantas untuk menjabat sebagai pemimpin. Akibatnya perempuan selalu dinomorduakan apabila ada kesempatan untuk memimpin. Seperti: (1) dalam proses pembangunan perempuan diikutsertakan tetapi tidak pernah diajak turut dalam mengambil keputusan dan pendapatnya jarang didengarkan, (2) dalam keluarga perempuan tidak diakui sebagai kepala rumah tangga, perempuan tidak boleh memimpin dan memerintah suami sekalipun suami tidak dapat memimpin, (c) dalam diri perempuan sendiri terdapat perasaan tidak mampu, lemah, inferior dan kurang oercaya diri.

2) Steorotip Masyarakat terhadap Perempuan 
Pandangan stereotip masyarakat yakni pembakuan diskriminasi antara perempuan dan laki-laki. Perempuan dan lakilaki sudah mempunyai sifat masingmasing yang sepantasnya, sehingga tidak dapat dikukur dari qodrat yang telah ada. Sebagai contoh: (1) urusan rumah tangga diserahkan kepada istri dan anak perempuan, pendidikan anak menjadi tanggungjawab ibu, dan mengurus suami diserahkan sepenuhnya kepada istri tanpa adanya upah, (2) kebanyakan perempuan memilih pekerjaan yang sudah dibagikan sesuai tanpa mempedulikan kemampuan atau potensi sebenarnya yang dimiliki, (3) jika seorang laki-laki memperkosa seorang perempuan, maka perempuan yang bertanggung jawab karena tugas perempuan tinggal dirumah.

3) Subordinasi terhadap Perempuan

Pandangan ini memposisikan perempuan dan karya-karyanya lebih rendah dari laki-laki. Posisi perempuan berada di bawah laki-laki dan menganggap bahwa perempuan tidak mampu berpikir.

4) Beban Ganda terhadap Perempuan

Pekerjaan yang diberikan kepada perempuan lebih lama mengerjakannya bila diberikan kepada laki-laki karena perempuan bekerja di sektor publik masih memiliki tanggung jawab pekerjaan rumah tangga yang tidak dapat di serahkan kepada pembantu rumah tangga sekalipun pembantu rumah tangga sama-sama perempuan.

5) Kekerasaan terhadap Perempuan

Kekerasan terhadap perempuan dapat berupa kekerasan psikis seperti: pelecehan, permintaan hubungan seks ditempat umum, senda gurau yang melecehkan perempua dan kekerasaan fisik seperti: pembunuhan, perkosaan, penganiayaan terhadap perempuan dan lain sebagainya. Sementara itu dalam pendidikan dasar persamaam pendidikan menghantarkan setiap individu atau rakyat mendapatkan pendidikan sehingga bisa disebut pendidikan kerakyatan. Ciri pendidikan kerakyataan adalah perlakuan dan kesempatan yang sama dan tidak membedakan pada jenis kelamin dan tingkat ekonomi, sosial, politik, agama dan lokasi geografi publik. Dalam kerangka ini pendidikan diperuntukkan untuk kalangan tanpa diskriminasi. Sebab manusia memiliki hak yang sama dalam mendapatkan pendidikan yang layak. Apabila ada sebagaian anggota masyarakat yang tersingkir dari kebijakan pendidikan berarti kebijakan tersebut telah meninggalkan sisi kemanusiaan yang setiap saat harus diperjuangkan

Pendidikan memang harus menyentuh kebutuhan dan relevan dengan tuntutan zaman yaitu kualitas memiliki keimanan dan hidup dalam ketaqwaan yang kokoh, mengenali, menghayati dan menerapkan akar budaya bangsa. Bagi kaum feminis kebijakan peningkatan pendidikan perempuan merupakan. Kesempatan untuk melanjutkan pendidikan bagi perempuan dijamin oleh konstitusi. Menurut pasal 7 Undang-Undang No. 20 tahun 2003 tentang Sistem Pendidikan Nasional menyebutkan bahwa kesempatan pendidikan pada satuan pendidikan tidak membedakan jenis kelamin, agama, suku, ras, kedudukan sosial, dan tingkat kemampuan ekonomi dan tetap mengindahkan kekhususan satuan pendidikan yang bersangkutan. Meskipun terlihat sederhana akan tetapi melalui hal ini bisa menjadi tonggak pertama dalam usaha mewujudkan kesetaraan gender pada tingkat lokal.

Dalam studi tentang kesetaraan gender pendidikan dianggap sebagai sebuah media kunci mewujudkan kesetaraan gender di masyarakat. Menurut Mursidah (2013) pendidikan merupakan alat mentransfer norma-norma masyarakat, pengetahuan dan kamampuan. Artinya melalui lembaga pendidikan berfungsi untuk mensosialisasikan norma dan nilai yang berlaku di masyarakat, termasuk gender. Dalam bidang pendidikan, perempuan masih tertinggal dibandingkan laki-laki. Karena mayoritas masyarakat masih menggap bahwa laki-laki harus dipriroitaskan untuk mendapatkan pendidikan daripada perempuan. Orang tua dari keluarga miskin biasanya lebih baik menikahkan anaknya atau didorong untuk menjadi pelayan di took, PRT (Pembantu Rumah Tangga) dan sektor informal lainya. Mereka tidak bisa mendapatkan hak memperoleh dan menikmati pendidikan yang berkualitas dan berbiaya murah. Atas kondisi yang diskrimnatif tersebut beberapa pegiat gender merumuskan bebrapa alternative sebagai upaya mengembangkan pendidikan berbasis gender (Mursidah, 2013):

A. Merumuskan reorientasi kurikulum pendidikan sekolah alternatif yang 
peduli terhadap kesetaraan gender, sehingga ada penghormatan terhadap hak-hak anak perempuan

B. Menydiakan secara khusus plafon subsidi anggaran pendidikan khusus untuk anak-anak usia sekolah dari komunitas perempuan, sehingga mereka bisa melanjutkan studi setidaknya sampai lulus jenjang sekolah menengah atas

C. Perlu diimplementasikan program visionaristik yakni perwujudan kesetaraan hak pendidikan bagi anak perempuan dalam seluruh proses tahap pendidikan.

D. Kesetaraan dalam mengaktualisasikan diri dalam proses dan kegiatan belajar mengajar.

Meskipun dengan meningkatnya pendidikan perempuan tidak secara otomatis akan mewujudkan kesetaraan gender. Akan tetapi melalui pendidikan, perempuan akan mempunyai akses lebih terhadap dunia luar. Selain itu arus pengetahuan terhadap perempuan akan jauh lebih luas, dan pemahaman yang matang terhadap peran dan status sosial masyarakat. Kebijakan pendidikan yang bersifat inklusif ini akan mendukung upaya pemerintah mengurangi praktek-praktek diskriminasi di masyarakat (Poernomo, 2016); (Erlin M, 2017)

Kebijakan pendidikan perempuan di Jawa tengah harus lebih digalakkan lagi. Misalnya saja dengan meningkatkan akses pendidikan melalui wajib belajar 12 tahun seperti di beberapa provinisi di Jawa Tengah. Dengan perubahan dan kompleksitas zaman yang terus berkembang. Perempuan harus mempunyai peran yang lebih dalam masyarakat. Perempuan harus ikut terlibat aktif dalam proses pengambilan keputusan. Tidak boleh ada batasan yang membatasi ruang bagi perempuan. Selama apa yang perempuan lakukan sama-sama mempunyai nilai kemanfaatan bagi masyarakat.

\section{SIMPULAN}

Kesetaraan gender merupakan sesuatu yang perlu kita perjuangkan bersama baik di tingkat nasional sampai lokal. Provinsi jawa tengah sebagai salah satu provinsi yang tingkat pernikahan usia dini relatif banyak, perlu memprioritaskan kesetaraan gender melalui peningkatan pendidikan berbasis kesetaraan gender terutama bagi perempuan. Pendidikan berbasis kesetaraan gender merupakan isu yang strategis. Hal itu bisa dikembangkan melalui Kurikulum, tenaga pendidikan yang berkompetensi mendukung kesetaraan gender, bahan dan buku ajar yang peka terhadap gender. Meningkatkan pendidikan perempuan seperti wajar (wajib belajar) 12 tahun. Dengan cara-cara itu kesetaraan gender bisa dipahami secara institusi dan bisa tertanam dalam nilai-nilai masyarakat di Provinsi Jawa Tengah

Penanaman nilai-nilai gender melalui institusi pendidikan akan memberikan pemahaman bagi masyarakat bahwa akses pendidikan boleh dinikmati siapa saja. Tidak hanya diprioritaskan untuk laki-laki saja. Dengan membuka lebar akses pendidikan tanpa terkecuali, akan lebih membuka kesempatan para perempuan untuk berkiprah di masyarakat. Dampak negative dari terbatasnya akses pendidikan bagi perempuan juga bisa berkurang. Apalagi dengan kompleksitas dan perubahan zaman yang terjadi saat ini. Kaum perempuan tidak hanya sebatas akan menjadi Ibu Rumah Tangga, akan tetapi juga mempunyai kesempatan yang sama dalam mengambil peran dan berkonstribusi aktif di masyarakat. Sehingga ketimpangan konstruksi sosial antar gender tidak jauh berbeda. Dengan semakin terdidiknya kaum perempuan, ini bisa mendukung peradaban bangsa dalam menyonsong bonus demografi di tahun-tahun yang akan datang.

\section{Referensi}

Abu, S. (2012). Konsep Pembelajaran Seni Budaya Berperspektif Gender (Study Kasus Bidang Studi Seni Tari Pada SMP di Kabupaten Kudus Provinsi Jawa Tengah). Chatarsis: Journal of Arts Education, 1(1), 1-8. Retrieved from https://journal.unnes.ac.id/sju/index.php/cat harsis/article/view/23

Creswell, J., \& Clark, V. P. (2010). The foundations of mixed methods research. Designing and Conducting Mixed Methods Research.

Efaningrum, A. (2008). Pendidikan dan Pemajuan Perempuan: Menuju Keadilan Gender. Yogyakarta: FSP FIP UNY.

Erlin M, A. . (2017). Policy of Inclusive Education for Education for All in Indonesia. Policy \& Governance Review, 1, 201-212. 
Fakih, M. (1997). Analisis Gender dan Transformasi Sosial. Yogyakarta: Pustaka Pelajar.

H. Dewi, S. (1997). Gender ditinjau dari Perspektif Sosiologi. Jakarta: Yayasan, 1997. Jakarta: Prakarsa Yogyakarta dan Fredrich Ebert Stuffing.

Marzuki. Studi Tentang Kesetaraan Gender dalam Berbagai Aspek. Fakultas Ilmu Sosial dan Ekonomi Universitas Negeri Yogyakarta. (2008). Studi Tentang Kesetaraan Gender dalam Berbagai Aspek. Studi Tentang Kesetaraan Gender Dalam Berbagai Aspek, (Kelompok 18), 1-13.

Mulyasa, E. (2006). Kurikulum Tingkat Satuan Pendidikan: Sebuah Panduan Praktis. Bandung: remaja Rosdakarya.

Mursidah. (2013). Pendidikan Berbasis Kesetaraan dan Keadilan Gender. Muwazah, 5(2), 277-292.

Mustaqim, M. (2014). Kurikulum Pendidikan Dasar Dalam Perspektif gender A . Pendahuluan Sebagaimana dipahami bersama bahwa pendidikan meru- pakan elemen penting dalam pembangunan karakter manusia . Melalui pendidikan, manusia mengetahui , mengenal, melaksanakan tema, kaida. Edukasia : Jurnal Penelitian Pendidikan Islam, 9(1), 113-128.
Poernomo, B. (2016). The Implementation of Inclusive Education in Indonesia: Current Problems and. American International Journal of Social Science, 144-150.

Puspitawati, H. (2013). Konsep, Teori dan Analisi Gender. Gender Dan Keluarga: Konsep Dan Realita Di Indonesia., 4(Zeitlin 1995), 1-16. https://doi.org/10.1017/S003358350100370 5

Susanti, R. D. (2015). Pendidikan Sastra Sensitif Gender : Alternatif Metode Pembelajaran Sastra Berperspektif Gender Untuk Jenjang Sekolah Dasar. PALASTREN, 8(2), 381398.

Suwitri, S. (2008). Konsep Dasar Kebijakan Publik. Semarang: Badan Penerbit Universitas Diponegoro.

Unicef;Bappenas. (2015). SDG's untuk anakanak di Indonesia: Profil Singkat Provinsi Jawa Tengah. 